\title{
Inconsistent Growth Response to Fertilization and Thinning of Lodgepole Pine in the Rocky Mountain Foothills Is Linked to Site Index
}

\author{
Bradley D. Pinno, ${ }^{1,2}$ Victor J. Lieffers, ${ }^{1}$ and Simon M. Landhäusser ${ }^{1}$ \\ ${ }^{1}$ Alberta School of Forest Science and Management, Faculty of Agricultural Life and Environmental Sciences, University of Alberta, \\ Edmonton, AB, Canada T6G $2 \mathrm{H} 1$ \\ ${ }^{2}$ Natural Resources Canada, Canadian Forest Service, Northern Forestry Centre, 5320122 Street, Edmonton, AB, Canada T6H $3 S 5$
}

Correspondence should be addressed to Bradley D. Pinno, bpinno@nrcan.gc.ca

Received 20 July 2012; Accepted 13 October 2012

Academic Editor: John Sessions

Copyright (C) 2012 Bradley D. Pinno et al. This is an open access article distributed under the Creative Commons Attribution License, which permits unrestricted use, distribution, and reproduction in any medium, provided the original work is properly cited.

Fertilization of conifers often results in highly variable growth responses across sites which are difficult to predict. The goal of this study was to predict the growth response of lodgepole pine (Pinus contorta var. latifolia) crop trees to thinning and fertilization using basic site and foliar characteristics. Fifteen harvest-origin stands along the foothills of the Rocky Mountains of Alberta were subjected to six treatments including two levels of thinning (thinning to 2500 stems per hectare and a control) and three types of fertilization (nitrogen-only fertilization, complete fertilization including nitrogen with added $\mathrm{P}, \mathrm{K}, \mathrm{S}, \mathrm{Mg}$, and $\mathrm{B}$, and no fertilization). After three growing seasons, the growth response and foliar status of the crop trees were examined and this response was related to site and foliar characteristics. There was a small and highly variable additive response to fertilization and thinning; diameter growth of crop trees increased relative to the controls an average of $0.3 \mathrm{~cm}$ with thinning, $0.3 \mathrm{~cm}$ with either $\mathrm{N}$-only or complete fertilization and $0.6 \mathrm{~cm}$ when thinned and fertilized. The increase in diameter growth with thinning and nitrogen-only fertilization was positively related to site index but not to any other site factors or pretreatment foliar variables such as nutrient concentrations, ratios, or thresholds.

\section{Introduction}

Lodgepole pine (Pinus contorta var. latifolia Loudon) is the dominant tree species in the foothills of Alberta and is capable of growing on a wide range of site types. Precommercial thinning of juvenile high density lodgepole pine stands can be used to avoid stand repression [1] and increase the growth of individual trees [2,3]. Fertilization is used to increase both individual tree growth and total stand volume [4]. Fertilization of lodgepole pine in North America usually focuses on nitrogen $(\mathrm{N})$ but limitations of other nutrients, including sulfur $(\mathrm{S})$, phosphorus $(\mathrm{P})$, boron $(\mathrm{B})$, and zinc $(\mathrm{Zn})$, have been identified in some sites in British Columbia $[5,6]$.

Fertilization of lodgepole pine and other conifers has been extensively studied around the world and a common finding has been that, on average, fertilizing conifer stands result in a significant increase in growth but there is usually high variability across sites. For example, five-year stem growth of Pinus sylvestris increased on average $45 \%$ after fertilization, but the growth response ranged from 11-104\% across 28 sites in Scandinavia [7] with no obvious connection between growth response and site characteristics.

For lodgepole pine, pretreatment foliar nutrient concentrations, their ratios with foliar $\mathrm{N}[8-10]$ and adequate foliar nutrient concentrations [11] have shown promise as diagnostic tools to predict site response to fertilization. For example, pretreatment foliar sulfate concentration and N/S ratios were successful in predicting lodgepole pine growth response to $\mathrm{N}$ and $\mathrm{N}+\mathrm{S}$ fertilization in British Columbia [4]. Other site variables including site index and soil type have been used to predict the response to midrotation fertilization 
TABLE 1: Site properties for each of the 15 stands.

\begin{tabular}{lcccccc}
\hline Site number & $\begin{array}{c}\text { Site index } \\
\text { (m @ 50 years) }\end{array}$ & $\begin{array}{c}\text { Age } \\
\text { (at breast height) }\end{array}$ & $\begin{array}{c}\text { Density } \\
\left(\text { stems ha }{ }^{-1}\right)\end{array}$ & $\begin{array}{c}\text { Basal area } \\
\left(\mathrm{m}^{2} \mathrm{ha}^{-1}\right)\end{array}$ & $\begin{array}{c}\text { Elevation } \\
(\mathrm{m})\end{array}$ & $\begin{array}{c}\text { Ecological subregion } \\
1\end{array}$ \\
\hline 20.3 & 18 & 8000 & 23.0 & 1238 & Upper foothills \\
2 & 20.4 & 16 & 11040 & 24.6 & 1281 & Upper foothills \\
3 & 19.5 & 9 & 5740 & 5.8 & 1197 & Upper foothills \\
4 & 21.7 & 6 & 5060 & 3.9 & 1104 & Lower foothills \\
5 & 19.7 & 22 & 8300 & 17.0 & 1064 & Lower foothills \\
6 & 21.6 & 21 & 8667 & 29.9 & 1041 & Lower foothills \\
7 & 19.3 & 12 & 11160 & 15.3 & 1341 & Upper foothills \\
8 & 21.4 & 7 & 6533 & 8.3 & 1255 & Upper foothills \\
9 & 18.2 & 15 & 2420 & 11.1 & 1346 & Lower foothills \\
10 & 16.6 & 19 & 3027 & 11.2 & 1473 & Upper foothills \\
11 & 18.7 & 4 & 9200 & 1.2 & 1480 & Upper foothills \\
12 & 20.8 & 18 & 6960 & 21.9 & 1084 & Upper foothills \\
13 & 18.8 & 18 & 9280 & 15.3 & 1169 & Upper foothills \\
14 & 18.4 & 18 & 14640 & 22.1 & 1208 & Upper foothills \\
15 & 22.5 & 9 & 10080 & 14.9 & 1096 & Lower foothills \\
\hline
\end{tabular}

of loblolly pine (Pinus taeda) in the southern United States [12], and these types of relationships between fertilization response and basic site and foliar characteristics may be applicable in Alberta.

Our study examines tree growth in relation to both thinning and fertilization applied to harvest origin lodgepole pine stands across a range of sites within the same ecological region. We examined site and foliar characteristics that might be used to predict response to treatment. Previous lodgepole pine thinning and fertilization studies have generally only examined a single site $[1,3]$ or compared stands from different ecological regions [13]. Our approach uses sites from a $350 \mathrm{~km}$ north-south transect across most of Alberta's foothills region and allows us to examine the differential growth benefits of thinning and fertilization over a large number of sites differing in productivity.

\section{Methods}

We studied 15 relatively pure lodgepole pine stands in the foothills of the Rocky Mountains in Alberta, Canada (Figure 1). Stands were of harvest origin, ranging in breast height age from 6 to 22 years, and were dominated by lodgepole pine (pine made up over $95 \%$ of the stand density in all but three of the stands). Site index, elevation, age, density, and other characteristics are given in Table 1. Within each stand, six $200 \mathrm{~m}^{2}$ square plots were established and randomly assigned to a thinning ( 2 levels) and fertilization treatment (3 levels). The thinning treatments were no thinning and a low thinning to a density of 2500 stems per hectare with all deciduous trees removed. The fertilization treatments were control (no fertilization), $\mathrm{N}$-only fertilization, and complete fertilizer blend with $\mathrm{N}$ and added P, K, S, magnesium (Mg), and B (Table 2).

Within each plot, all conifer trees were measured before treatment for height and diameter at breast height (DBH). Thinning and fertilization treatments were carried out by

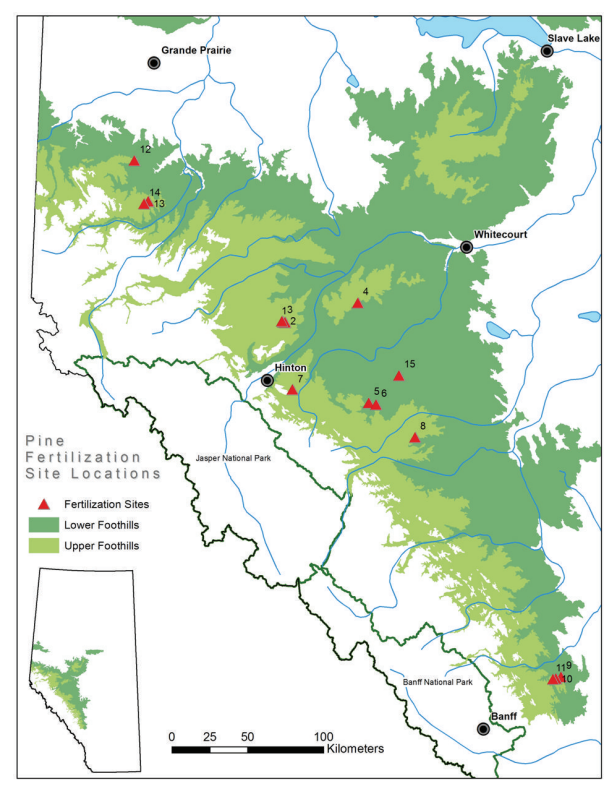

Figure 1: Map of the study region in the foothills of Alberta.

hand in May of 2006. All trees were remeasured the following winter and again after three growing seasons. After the first and third growing seasons, foliar samples were also collected during the winter from the upper third of the crown of three dominant or codominant lodgepole pine trees. A sample of 100 needle fascicles of the youngest age class was isolated from each tree and the dry weight was determined after drying at $68^{\circ} \mathrm{C}$. Samples were ground and pooled for foliar nutrient analysis, including foliar $\mathrm{N}, \mathrm{P}, \mathrm{K}$, $\mathrm{S}$, calcium $(\mathrm{Ca}), \mathrm{Mg}$, sulfate $\left(\mathrm{SO}_{4}\right), \mathrm{B}$, copper $(\mathrm{Cu}), \mathrm{Zn}$, manganese $(\mathrm{Mn})$, and iron $(\mathrm{Fe})$ concentrations. Nitrogen concentration was determined colourimetrically using an autoanalyzer after digestion with $\mathrm{H}_{2} \mathrm{SO}_{4}$ while $\mathrm{K}, \mathrm{Ca}, \mathrm{Mg}$, 
TABLE 2: Fertilizer formulations for N-only and complete fertilizers.

\begin{tabular}{|c|c|c|c|c|c|c|c|}
\hline & \multirow{2}{*}{ Ingredient } & \multicolumn{6}{|c|}{ Nutrients $\left(\mathrm{kg} \mathrm{ha}^{-1}\right)$} \\
\hline & & $\mathrm{N}$ & $\mathrm{P}$ & K & $\mathrm{S}$ & $\mathrm{Mg}$ & B \\
\hline \multirow{4}{*}{ N-only fertilizer } & Urea & 300 & & & & & \\
\hline & Total & 300 & 0 & 0 & 0 & 0 & 0 \\
\hline & Urea & 251 & & & & & \\
\hline & Monoammonium phosphate & 49 & 100 & & 7 & & \\
\hline \multirow[t]{4}{*}{ Cbmplete fertilizer } & Muriate of potash & & & 46 & & & \\
\hline & Sulphate potassium magnesia & & & 54 & 68 & 33 & \\
\hline & Borate granular & & & & & & 3 \\
\hline & Total & 300 & 100 & 100 & 75 & 33 & 3 \\
\hline
\end{tabular}

$\mathrm{Cu}, \mathrm{Zn}$, and $\mathrm{Mn}$ were determined by atomic absorption after the same digestion. The azomethine- $\mathrm{H}$ method was used to determine $\mathrm{B}$ concentration after dry ashing. Available $\mathrm{SO}_{4}$ was determined colourimetrically on a HI-bismuth reducible distillate after $0.1 \mathrm{~N} \mathrm{HCl}$ extraction. Active $\mathrm{Fe}$ concentration was determined by atomic absorption after $1 \mathrm{~N} \mathrm{HCl}$ extraction.

Growth rate per tree was determined for each plot based on the largest 12 stems (600 stems per hectare). This approach was taken because a snow storm damaged 9 of the 15 of the stands, with damage concentrated on the medium- and smaller-sized trees [14]. Only in the thinning + fertilization treatments were some of the larger trees affected. By concentrating on the largest trees, the impact of the snow damage on growth responses can be greatly reduced and still allows for meaningful comparisons among treatments. Analyzing the growth response of the largest trees in stands has been done previously $[1,15]$ and is relevant as these trees can be considered the crop trees that will likely survive to final harvest. Growth increment was calculated as tree size (DBH and volume) after three growing seasons minus the initial tree size prior to treatment. Stem volume was calculated using a taper volume equation developed for the area [16]. Foliar $\mathrm{N}$ mass per 100 fascicles was determined by multiplying $\mathrm{N}$ concentration by the mass of 100 fascicles. Foliar $\mathrm{N}$ uptake as a result of the treatments was estimated by subtracting the foliar $\mathrm{N}$ mass per 100 fascicles of the control plot from the foliar $\mathrm{N}$ mass of the treatment plots.

Statistical analysis involved comparing growth and foliar characteristics among treatments using two-way ANOVAs $(3 \times 2)$ blocked by site. Tukey's HSD test was used to further examine differences among treatment levels. To evaluate the differential response to fertilization and thinning between sites, differential growth increment (treatment growthcontrol growth) was regressed against site conditions, including site index, density, elevation, and age, and foliar properties, including foliar mass, nutrient concentrations, ratios, uptake, and adequate nutrient values, of the control plots. Statistical analysis was conducted using JMP 8.0 (SAS Institute Inc., Cary, NC, USA).

\section{Results}

Thinning and fertilization had an additive impact on individual tree growth of the 600 crop trees $\mathrm{ha}^{-1}$ after the third growing season, increasing diameter growth from $1.4 \mathrm{~cm}$ in the control plots to an average of 1.7 in the thinned or fertilized plots to greater than $2.0 \mathrm{~cm}$ in the thinned + fertilized plots (Figure 2(a)). However, the differential diameter growth increment was highly variable ranging from -0.12 to $1.27 \mathrm{~cm}$ diameter growth across treatments. Relative to the control plots, this corresponds to a diameter growth increase of $22 \%$ with thinning, $24 \%$ with $\mathrm{N}$-only fertilization, $25 \%$ with complete fertilization and $47 \%$ with thinning and fertilization combined. For volume growth, only the thinning + fertilization treatments resulted in significantly greater growth than the controls (Figure 2(b)). Overall, there was a positive effect of thinning and fertilization on both diameter and volume increment, but there was no difference in average growth response between $\mathrm{N}$-only and complete fertilization either with or without thinning.

Initial foliar $\mathrm{N}$ concentrations ranged from $1.02-1.23 \%$ $\mathrm{N}$. The first year after treatment, foliar $\mathrm{N}$ concentration increased with complete fertilization (both with and without thinning) and thinning $+\mathrm{N}$-only fertilization reaching an average of $1.48 \% \mathrm{~N}$, while the $\mathrm{N}$-only treatment without thinning was $1.35 \% \mathrm{~N}$ and the control fertilization plots (either unthinned or thinned) were less than $1.14 \% \mathrm{~N}$ (Figure 3(a)). After three growing seasons, foliar $\mathrm{N}$ concentrations were not significantly different from the control plots in all but the unthinned + complete fertilization plots (Figure 3(a)).

Foliar mass responded strongly to the combination of thinning and fertilization the first year after treatment (Figure 3(b)). Thinning or $\mathrm{N}$-only fertilization alone did not increase foliar mass while the highest foliar mass was in the thinning + complete fertilization treatment. After three growing seasons, foliar mass was not significantly different from the control plots in any of treatments. Crop tree foliar nitrogen uptake increased with fertilization with the greatest average uptake in the thinning + complete fertilization treatment (Figure 4). There was great variability among sites, however, with 4 of the 15 sites showing no foliar $\mathrm{N}$ uptake with $\mathrm{N}$-only fertilization alone, 8 of the 15 sites showing no foliar $\mathrm{N}$ uptake with thinning only and many other treatment units showing very little foliar $\mathrm{N}$ uptake.

After one growing season, foliar $\mathrm{P}$ concentration increased in response to complete fertilization (Table 3). Foliar S concentration increased with complete fertilization 


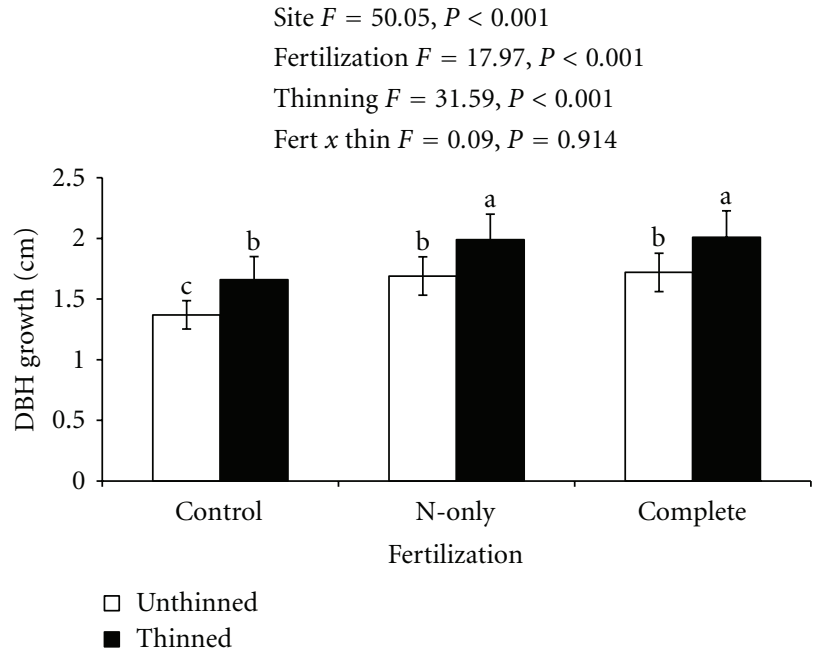

(a) Diameter

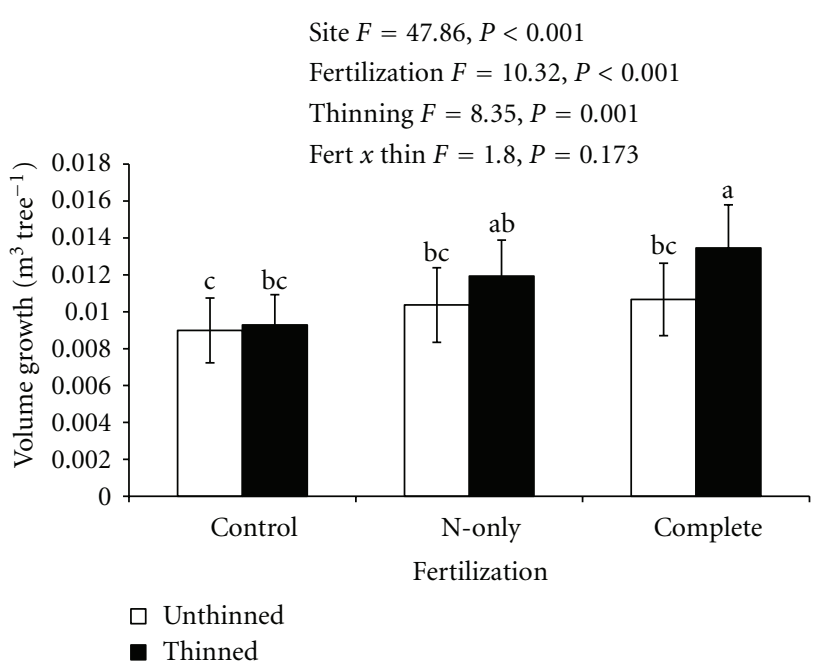

(b) Volume

Figure 2: Three-year crop tree diameter (a) and volume (b) growth in relation to thinning and fertilization treatments. Letters represent differences in total growth among the six treatments.

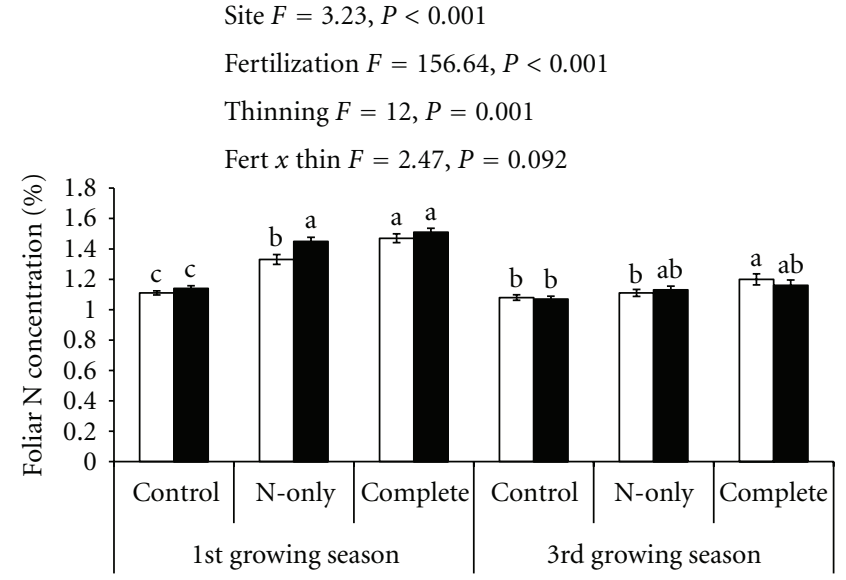

(a)

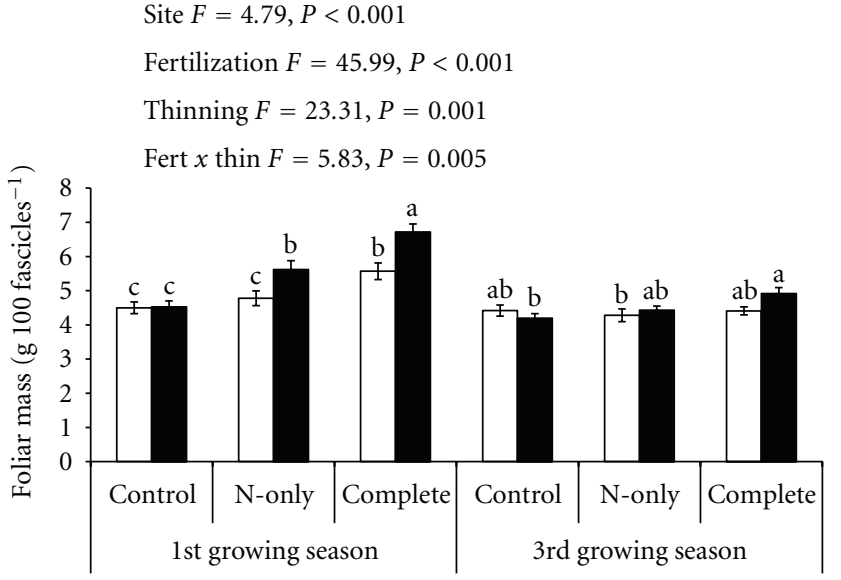

(b)

FIgURE 3: Response of (a) foliar nitrogen concentration and (b) mass of 100 fascicles to thinning and fertilization treatments after 1 and 3 growing seasons. White bars represent unthinned stands and black bars represent thinned stands. Different letters represent significant differences among treatments for each growing season. ANOVA statistics are given for the 1st growing season data.

but $\mathrm{SO}_{4}$ concentration decreased with $\mathrm{N}$-only fertilization. Foliar base cation concentrations $(\mathrm{K}, \mathrm{Ca}$, and $\mathrm{Mg})$ did not respond significantly to either fertilization or thinning but foliar $\mathrm{K}$ concentration tended to increase with complete fertilization while $\mathrm{Mg}$ tended to decrease with all fertilizer treatments. Foliar B concentration increased with complete fertilization but tended to decrease with $\mathrm{N}$-only fertilization. Foliar Fe decreased with complete fertilization while $\mathrm{Zn}$, $\mathrm{Cu}$ and $\mathrm{Mn}$ did not respond to the treatments. After three growing seasons, only $\mathrm{B}$ and $\mathrm{SO}_{4}$ concentrations were still significantly different from the controls.

We could not detect any correlations between growth differential (treatment growth-control growth) and prethinning density, elevation, age, foliar mass, foliar nutrient concentrations, nutrient ratios, or nutrient thresholds of the controls. Further, the growth differential was not related to estimated foliar $\mathrm{N}$ uptake among sites for any of the treatments (Figure 4). We did, however, find that diameter growth differential increased with site index in the thinning only, $\mathrm{N}$-only fertilization, and thinning $+\mathrm{N}$-only fertilization treatments (Figures 5(a) and 5(b)); there was no correlation of diameter growth differential with site index in the complete fertilization treatments (Figure 5(c)).

\section{Discussion}

Thinning and fertilization produced an additive growth response in lodgepole pine with the best growth occurring when plots were both thinned and fertilized-diameter growth after three growing seasons increased on average 
TABLe 3: Foliar nutrient concentrations after the first growing season in relation to thinning and fertilization treatments. Letters represent significant differences between treatments.

\begin{tabular}{|c|c|c|c|c|c|c|c|c|c|c|c|c|}
\hline Thinning & Fertilization & $\begin{array}{c}\mathrm{P} \\
(\%)\end{array}$ & $\begin{array}{c}\mathrm{K} \\
(\%)\end{array}$ & $\begin{array}{c}\mathrm{S} \\
(\%)\end{array}$ & $\begin{array}{c}\mathrm{Ca} \\
(\%)\end{array}$ & $\begin{array}{l}\mathrm{Mg} \\
(\%)\end{array}$ & $\begin{array}{l}\mathrm{So}_{4}{ }^{-} \\
(\mathrm{ppm})\end{array}$ & $\begin{array}{c}\mathrm{B} \\
(\mathrm{ppm})\end{array}$ & $\begin{array}{c}\mathrm{Cu} \\
(\mathrm{ppm})\end{array}$ & $\begin{array}{c}\mathrm{Zn} \\
(\mathrm{ppm})\end{array}$ & $\begin{array}{c}\mathrm{Fe} \\
(\mathrm{ppm})\end{array}$ & $\begin{array}{c}\mathrm{Mn} \\
(\mathrm{ppm})\end{array}$ \\
\hline \multirow{3}{*}{ Unthinned } & Control & $0.132^{c}$ & 0.409 & $0.089^{b c}$ & 0.187 & 0.082 & $127.7^{\mathrm{a}}$ & $11.16^{\mathrm{b}}$ & 3.49 & 45.6 & $53.3^{\mathrm{ab}}$ & 370.3 \\
\hline & $\mathrm{N}$-only & $0.133^{b c}$ & 0.407 & $0.088^{\mathrm{c}}$ & 0.182 & 0.075 & $48.7^{\mathrm{b}}$ & $8.67^{\mathrm{b}}$ & 3.29 & 43.8 & $47.7^{\mathrm{bc}}$ & 360.7 \\
\hline & Complete & $0.149^{\mathrm{a}}$ & 0.435 & $0.108^{\mathrm{a}}$ & 0.189 & 0.075 & $94.9^{\mathrm{a}}$ & $34.29^{\mathrm{a}}$ & 3.23 & 42.7 & $44.5^{\mathrm{c}}$ & 360.7 \\
\hline \multirow{3}{*}{ Thinned } & Control & $0.135^{\mathrm{bc}}$ & 0.413 & $0.091^{b c}$ & 0.211 & 0.084 & $121.2^{\mathrm{a}}$ & $11.78^{\mathrm{b}}$ & 3.54 & 45.4 & $54.9^{\mathrm{a}}$ & 400.8 \\
\hline & $\mathrm{N}$-only & $0.143^{\mathrm{ab}}$ & 0.405 & $0.096^{\mathrm{b}}$ & 0.187 & 0.077 & $48.6^{\mathrm{b}}$ & $8.93^{\mathrm{b}}$ & 3.77 & 44.7 & $48.9^{\mathrm{abc}}$ & 360.5 \\
\hline & Complete & $0.150^{\mathrm{a}}$ & 0.447 & $0.111^{\mathrm{a}}$ & 0.189 & 0.075 & $97.8^{\mathrm{a}}$ & $32.10^{\mathrm{a}}$ & 3.48 & 43.5 & $46.6^{c}$ & 378.0 \\
\hline
\end{tabular}

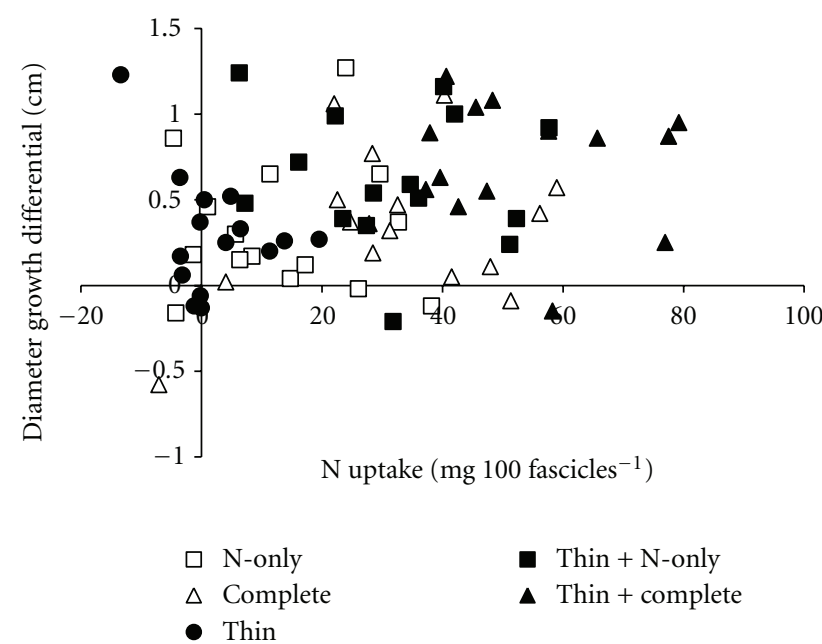

FIGURE 4: Diameter growth differential of thinning and fertilization treatments relative to the controls in relation to nitrogen uptake by the foliage in year 1 ( $\mathrm{N}$ content of treated trees $-\mathrm{N}$ content of control trees). Diameter growth differential is the difference between $\mathrm{DBH}$ growth after three years of the treated stand and $\mathrm{DBH}$ growth of the associated control stand.

$0.3 \mathrm{~cm}$ with thinning, $0.3 \mathrm{~cm}$ with either $\mathrm{N}$-only or complete fertilization, and $0.6 \mathrm{~cm}$ with thinning and fertilization combined. This additive crop tree growth response to thinning and fertilization has been recorded before in lodgepole pine stands $[1,3,13]$; however, the real story of our study relates to our inability to diagnose which stands would respond to treatment, particularly for the complete fertilization treatment.

All stands had low foliar $\mathrm{N}$ concentrations prior to treatment (average 1.1\%) compared to the adequate value of $1.35 \% \mathrm{~N}$ [11]. We therefore expected a greater growth increase as a result of the fertilization. Further, many of our sites showed little or no positive growth response to our treatments which is a disappointing result given that all of the sites were below the critical level of foliar $\mathrm{N}$ prior to treatment and the high rate of fertilizer applied (300 kg N ha-1 along with other nutrients). This inconsistent response to fertilization is similar to what has been found in other conifer fertilization studies (e.g., in lodgepole pine [4, 17], Picea glauca [18], Picea abies [19], Pseudotsuga menziesii [20], and mixed conifer stands of the Pacific Northwest [21]).

Foliar nutrient concentrations and ratios have been successfully used in predicting the growth response of lodgepole pine to fertilization $[4,6]$ but did not work in our study. We believe that the main reason that these techniques were not useful in our study is that in many of the sites the nutrients supplied by the fertilizer were not successfully taken up by the trees. These diagnostic tests can only work well if the tree actually takes up the nutrients. In our study, at 4 of the 15 sites, trees showed no uptake of $\mathrm{N}$ in the $\mathrm{N}$-only treatment and another 4 sites had only a small amount of uptake.

The uptake of $\mathrm{N}$ may be related to the type of fertilization applied with the complete formulation resulting in greater $\mathrm{N}$ uptake, even though the total amount of $\mathrm{N}$ applied was the same between the $\mathrm{N}$-only and complete fertilization treatments. This increased $\mathrm{N}$ uptake with complete fertilization could simply be related to increased tree growth stimulating greater uptake of $\mathrm{N}$. The addition of other potentially limiting nutrients can also increase $\mathrm{N}$ uptake as has been seen previously in Eucalyptus grandis, where fertilization with $\mathrm{P}$ increased $\mathrm{N}$ absorption through a mechanism not related to increased $\mathrm{N}$ demand [22]. The difference in fertilizer formulation may have also affected $\mathrm{N}$ uptake; in the $\mathrm{N}$-only fertilizer urea was the single source for $\mathrm{N}$ while in the complete fertilizer $49 \mathrm{~kg} \mathrm{Nha}^{-1}$ was derived from monoammonium phosphate. This direct addition of $\mathrm{NH}_{4}$ could have made $\mathrm{N}$ more readily available for uptake since the $\mathrm{N}$ from monoammonium phosphate may have been less likely to be volatilized than the $\mathrm{N}$ derived from urea [23] in these forests with thick organic layers. It is likely that ammonium nitrate is a better formulation than urea for $\mathrm{N}$ fertilization in boreal forests [24].

Even when $\mathrm{N}$ was increased in the foliage, there were sometimes poor tree growth responses and we suggest that these were related to internal nutrient imbalances. With the addition of $\mathrm{N}$-only fertilizer, macronutrient imbalances can be induced in lodgepole pine [4] and other conifers [25]. Micronutrient deficiencies ( $\mathrm{Cu}$ and $\mathrm{Zn}$ ) have also developed after repeated $\mathrm{N}$ fertilization of lodgepole pine, thereby limiting potential growth [5]. In our study, the idea that nutrient imbalances limit growth response is supported by the fact that only the $\mathrm{N}$-only and thinning-only treatments had a positive relationship between growth differential and 


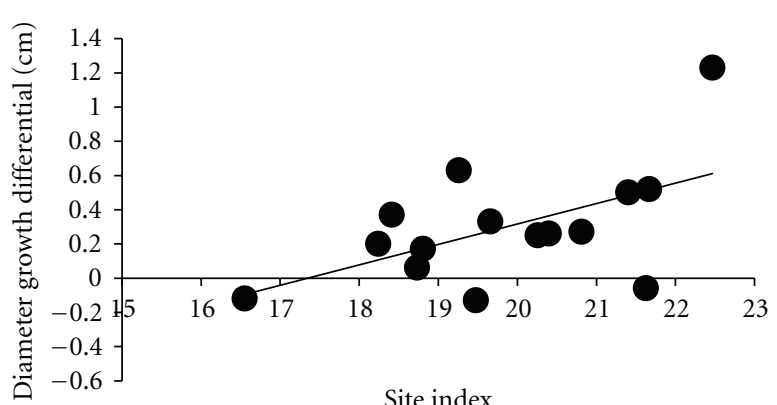

(a) Thin only

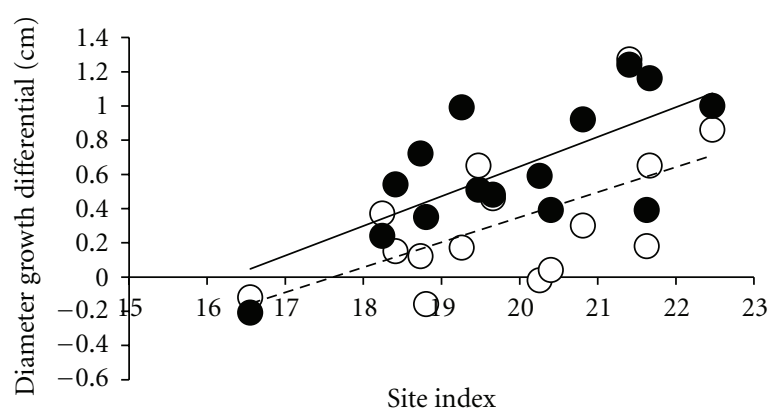

(b) N-only fertilization

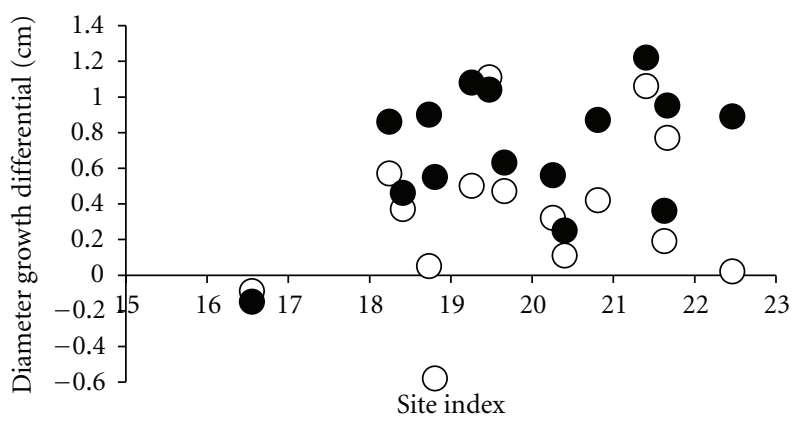

(c) Complete fertilization

FIGURE 5: Diameter growth differential of thinning and fertilization treatments relative to site index of the control stands. The response variable, diameter growth differential, is the difference between DBH growth after three years of the treated stand and DBH growth of the associated control stand. White dots represent unthinned plots and black dots represent thinned plots. (a) Thin only, $P=0.032, r^{2}=0.254$, (b) N-only, $P=0.020, r^{2}=0.303$, N-only + thinning, $P=0.003, r^{2}=0.469$, and (c) complete fertilization, $P=0.334$, complete + thinning, $P=0.110$.

site index. We argue that sites with low site index are likely limited by several nutrients so thinning or N-only fertilization will not result in increased growth. On betterquality sites, other nutrients such as $\mathrm{P}, \mathrm{S}$, and micronutrients, are likely in higher supply so $\mathrm{N}$-only fertilization and thinning will increase growth without causing internal nutrient imbalances or inducing other nutrient deficiencies. In contrast, the differential growth response to complete fertilizer was not related to site index, likely because any potential nutrient imbalances were eliminated.

The link between site index and growth response to silvicultural treatments has been varied. For example, growth response to competition control in hybrid poplar plantations was positively correlated to site productivity [26], while in jack pine plantations the growth response to site preparation treatments was negatively correlated to site productivity [27]. The positive relationship between lodgepole pine growth response to thinning and $\mathrm{N}$-only fertilization and site index has not previously been documented but appears to be related to site nutrient availability and nutrient imbalances.

In summary, the combination of fertilization and thinning is likely to result in the greatest growth response of lodgepole pine crop trees. On better quality sites it may be possible to use $\mathrm{N}$-only fertilizer but the poorer sites may also need other nutrients in order to stimulate a growth response. We recommend caution in extrapolating the growth results in our study to yield at the stand level because our study focused on the response of only the largest trees in the stand, that is, the crop trees. Future work should concentrate on identifying specific fertilizer formulations, particularly the forms of $\mathrm{N}$, and their delivery methods to enhance nutrient uptake of trees in the field.

\section{Acknowledgments}

The authors thank Dick Dempster for directing the establishment and measurement of the study plots. Funding was provided by the Foothills Growth and Yield Association, the Forest Resource Improvement Association of Alberta, and the National Sciences and Engineering Research Council of Canada.

\section{References}

[1] C. Farnden and L. Herring, "Severely repressed lodgepole pine responds to thinning and fertilization: 19-year results," Forestry Chronicle, vol. 78, no. 3, pp. 404-414, 2002.

[2] X. Liu, U. Silins, V. J. Lieffers, and R. Man, "Stem hydraulic properties and growth in lodgepole pine stands following thinning and sway treatment," Canadian Journal of Forest Research, vol. 33, no. 7, pp. 1295-1303, 2003.

[3] R. C. Yang, "Foliage and stand growth responses of semimature lodgepole pine to thinning and fertilization," Canadian Journal of Forest Research, vol. 28, no. 12, pp. 1794-1804, 1998. 
[4] R. P. Brockley, "Using foliar variables to predict the response of lodgepole pine to nitrogen and sulphur fertilization," Canadian Journal of Forest Research, vol. 30, no. 9, pp. 13891399, 2000.

[5] I. G. Amponsah, P. G. Comeau, R. P. Brockley, and V. J. Lieffers, "Effects of repeated fertilization on needle longevity, foliar nutrition, effective leaf area index, and growth characteristics of lodgepole pine in interior British Columbia, Canada," Canadian Journal of Forest Research, vol. 35, no. 2, pp. 440 451, 2005.

[6] R. E. Carter and R. P. Brockley, "Boron deficiencies in British Columbia: diagnosis and treatment evaluation," Forest Ecology and Management, vol. 37, no. 1-3, pp. 83-94, 1990.

[7] U. Sikström, H. Ö. Nohrstedt, F. Pettersson, and S. Jacobson, "Stem-growth response of Pinus sylvestris and Picea abies to nitrogen fertilization as related to needle nitrogen concentration,” Trees, vol. 12, no. 4, pp. 208-214, 1998.

[8] R. P. Brockley, "Response of thinned, immature lodgeopole pine to nitrogen and boron fertilization," Canadian Journal of Forest Research, vol. 20, no. 5, pp. 579-585, 1990.

[9] R. P. Brockley and F. J. Sheran, "Foliar nutrient status and fascicle weight of lodgepole pine after nitrogen and sulphur fertilization in the interior of British Columbia," Canadian Journal of Forest Research, vol. 24, no. 4, pp. 792-803, 1994.

[10] B. E. Kishchuk and R. P. Brockley, "Sulfur availability on lodgepole pine sites in British Columbia," Soil Science Society of America Journal, vol. 66, no. 4, pp. 1325-1333, 2002.

[11] R. P. Brockley, "Foliar sampling guidelines and nutrient interpretative criteria for lodgepole pine," Extension Note 52, B.C. Ministry of Forests, Victoria, Canada, 2001.

[12] T. R. Fox, H. L. Allen, T. J. Albaugh, R. Rubilar, and C. A. Carlson, "Tree nutrition and forest fertilization of pine plantations in the southern United States," Southern Journal of Applied Forestry, vol. 31, no. 1, pp. 5-11, 2007.

[13] P. M. F. Lindgren, T. P. Sullivan, D. S. Sullivan, R. P. Brockley, and R. Winter, "Growth response of young lodgepole pine to thinning and repeated fertilization treatments: 10-year results," Forestry, vol. 80, no. 5, pp. 587-611, 2007.

[14] F. P. Teste and V. J. Lieffers, "Snow damage in lodgepole pine stands brought into thinning and fertilization regimes," Forest Ecology and Management, vol. 261, no. 11, pp. 2096-2104, 2011.

[15] D. P. Blevins, C. E. Prescott, H. L. Allen, and T. A. Newsome, "The effects of nutrition and density on growth, foliage biomass, and growth efficiency of high-density fire-origin lodgepole pine in central British Columbia," Canadian Journal of Forest Research, vol. 35, no. 12, pp. 2851-2859, 2005.

[16] S. M. Huang, "Ecologically based individual tree volume estimation for major Alberta tree species," Report \#1, Alberta Sustainable Resource Development, Edmonton, Canada, 1994.

[17] B. E. Kishchuk, G. F. Weetman, R. P. Brockley, and C. E. Prescott, "Fourteen-year growth response of young lodgepole pine to repeated fertilization," Canadian Journal of Forest Research, vol. 32, no. 1, pp. 153-160, 2002.

[18] R. F. Sutton, "White spruce establishment: initial fertilization, weed control, and irrigation evaluated after three decades," New Forests, vol. 9, no. 2, pp. 123-133, 1995.

[19] K. Dralle and J. B. Larsen, "Growth response to different types of NPK-fertilizer in Norway spruce plantations in Western Denmark," Plant and Soil, vol. 168-169, no. 1, pp. 501-504, 1995.
[20] D. Binkley and P. Reid, "Long-term responses of stem growth and leaf area to thinning and fertilization in a Douglas-fir plantation," Canadian Journal of Forest Research, vol. 14, no. 5, pp. 656-660, 1984.

[21] R. Rose and J. S. Ketchum, "Interaction of vegetation control and fertilization on conifer species across the Pacific Northwest," Canadian Journal of Forest Research, vol. 32, no. 1, pp. 136-152, 2002.

[22] C. Graciano, J. F. Goya, J. L. Frangi, and J. J. Guiamet, "Fertilization with phosphorus increases soil nitrogen absorption in young plants of Eucalyptus grandis," Forest Ecology and Management, vol. 236, no. 2-3, pp. 202-210, 2006.

[23] D. E. Kissel, M. L. Cabrera, and R. B. Ferguson, "Reactions of ammonia and urea hydrolysis products with soil," Soil Science Society of America Journal, vol. 52, no. 6, pp. 1793-1796, 1988.

[24] R. F. Fisher and D. Binkley, Ecology and Management of Forest Soils, John Wiley \& Sons, New York, NY, USA, 3rd edition, 2000.

[25] M. T. Garrison, J. A. Moore, T. M. Shaw, and P. G. Mika, "Foliar nutrient and tree growth response of mixed-conifer stands to three fertilization treatments in Northeast Oregon and North central Washington," Forest Ecology and Management, vol. 132, no. 2-3, pp. 183-198, 2000.

[26] B. D. Pinno and N. Bélanger, "Competition control in juvenile hybrid poplar plantations across a range of site productivities in central Saskatchewan, Canada," New Forests, vol. 37, no. 2, pp. 213-225, 2009.

[27] F. Marquis and D. Paré, "The role of permanent site factors in the assessment of soil treatment effects: a case study with a site preparation trial in jack pine plantations on glacial outwashes," Canadian Journal of Soil Science, vol. 89, no. 1, pp. 81-91, 2009. 

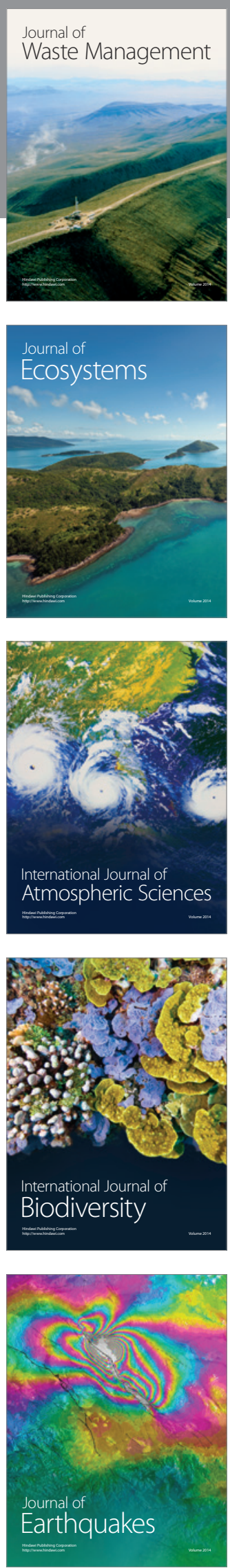
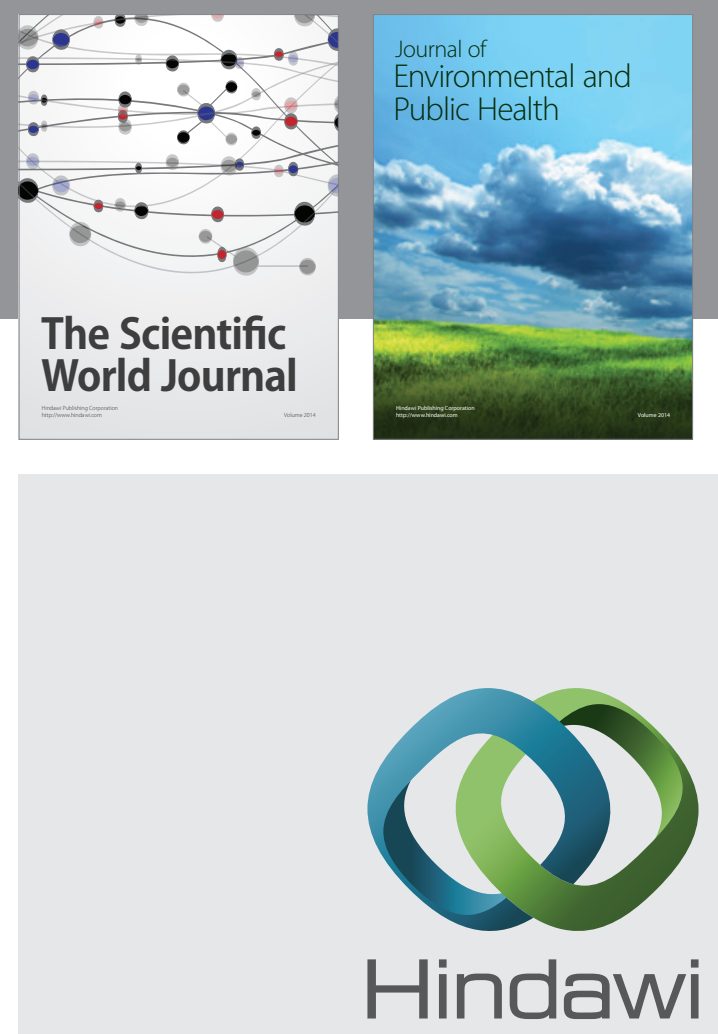

Submit your manuscripts at

http://www.hindawi.com
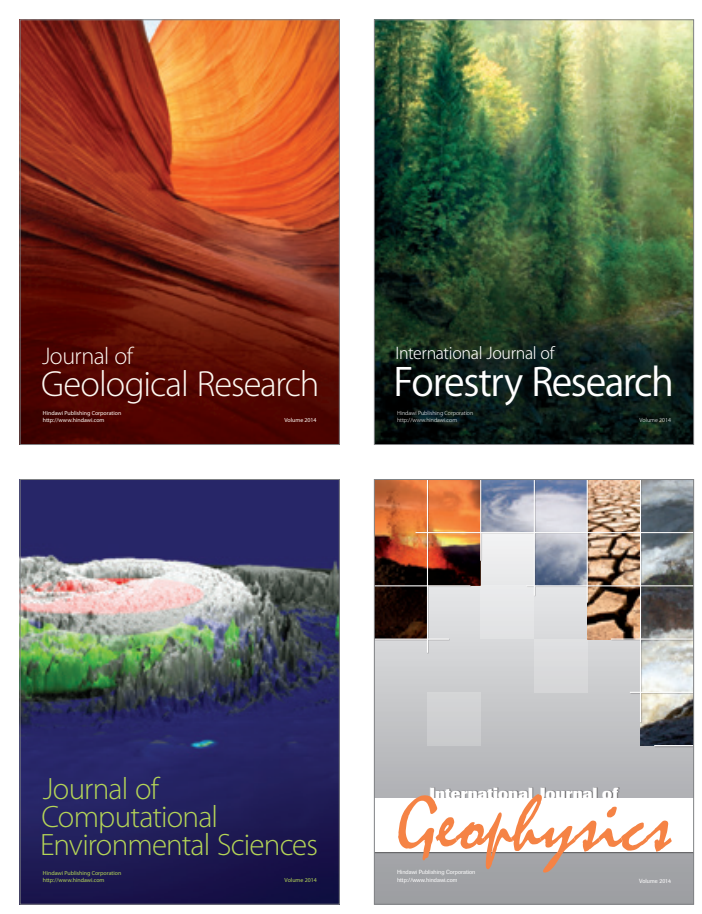
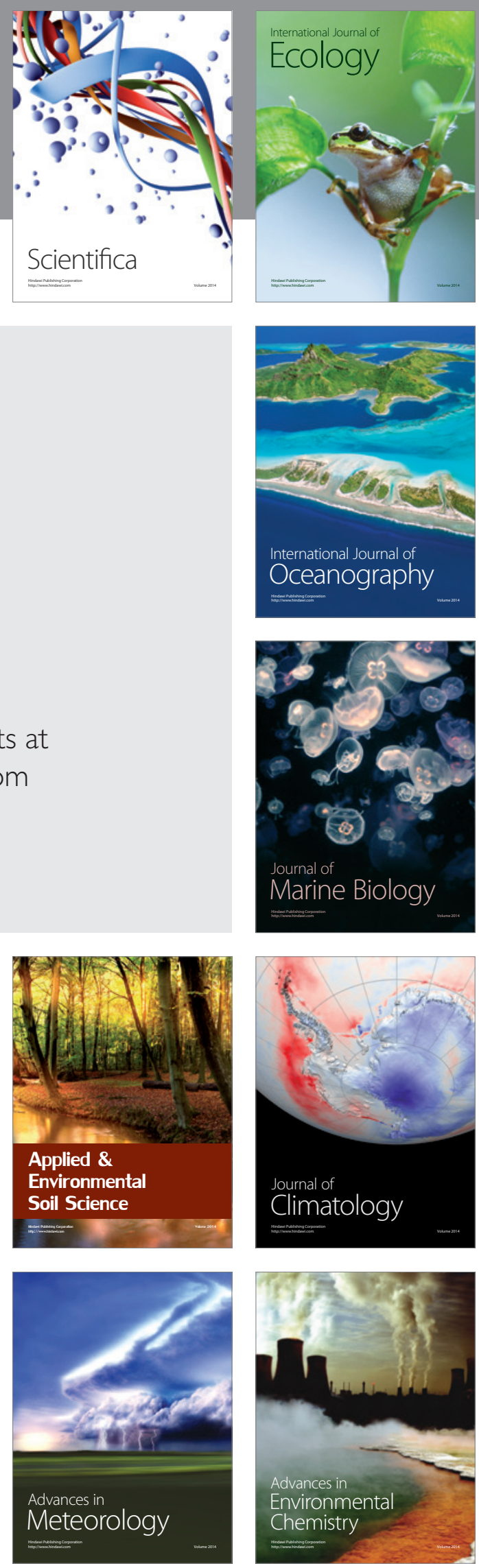